\title{
SOMATIC EMBRYOGENESIS IN GOIABEIRA SERRANA: GENOTYPE RESPONSE, AUXINIC SHOCK AND SYNTHETIC SEEDS
}

\author{
MIGUEL P. GUERRA ${ }^{1}$, LIRIO L. DAL VESCO ${ }^{2}$, JEAN PIERRE H.J. DUCROQUET ${ }^{3}$, \\ RUBENS O. NODARI ${ }^{1}$ AND MAURÍCIO S. DOS REIS ${ }^{1}$
}

\begin{abstract}
Laboratório de Fisiologia do Desenvolvimento e Genética Vegetal, Departamento de Fitotecnia, Centro de Ciências Agrárias, Universidade Federal de Santa Catarina, Brasil; and Estação Experimental de

Videira, EPAGRI, SC, Brazil.
\end{abstract}

\begin{abstract}
The induction and control of in vitro somatic embryogenesis is dependent of a number of factors. The genotype of the mother plant donor of explants and the kind of auxin play essential roles in conferring embryogenic competence. Once obtained somatic embryos may be encapsulated in alginate originating synthetic seeds that can be stored at low temperatures. Considering this the present work aimed at the assessment of five different genotypes, five periods of 2,4-D shock ( $20 \mu \mathrm{M}$ for 1, 2, 4, 8 and 16 weeks) (), and different substances supplemented to sodium alginate to obtain synthetic seeds. Zygotic embryos of Feijoa sellowiana were inoculated in basal LP medium (von Arnold and Erikson, 1981) supplemented with Morel's vitamins, sucrose (3\%) and phytagel $(0.2 \%)$. The highest rates of somatic embryogenesis induction were observed in the genotypes 50-4 and 101. Shock of two weeks in 2,4-D conferred embryogenic competence in the same levels obtained with the shock of 8 weeks. Histological evaluations revealed the direct origin of the somatic embryos from the epidermic surface of cotyledons. Synthetic seeds containing MS salts and sucrose resulted in higher rates of contamination than capsules free of these substances. $\mathrm{KNO}_{3}(100 \mathrm{mM})$ resulted in the opening of $81.2 \%$ of the capsules as compared to $0 \%$ of opening in the treatment with water.
\end{abstract}

ADDITIONAL INDEX TERMS: Acca sellowiana, micropropagation, pineapple-guava, encapsulation.

ABBREVIATIONS: CH - Casein Hydrolysate; 2,4-D - 2,4- dichlorophenoxyacetic acid; $\mathrm{GA}_{3}$ - gibberellic acid; Gln - L-glutamine; LPm - von Arnold and Eriksson (1981) modified medium; Kin - Kinetin; 1/2MS half strength Murashige and Skoog's; SE - somatic embryos; somatic embryogenesis; ZE -zygotic embryos.

\section{EMBRIOGÊNESE SOMÁTICA EM GOIABEIRA SERRANA: EFEITO DO GENÓTIPO, CHOQUE AUXÍNICO E SEMENTES SINTÉTICAS}

RESUMO - A embriogênese somática in vitro é dependente de uma série de fatores, dentre os quais o genótipo da planta matriz doadora de explantes e a fonte de auxina para conferir competência embriogênica são considerados como determinativos. Uma vez obtidos, os embriões somáticos podem ser encapsulados em alginato para a obtenção de sementes sintéticas, permitindo assim o armazenamento em baixas temperaturas e o posterior cultivo de maneira semelhante à semente verdadeira. Os aspectos cita-

Received: 22.03.01 - Accepted: 04-06-01

1. Corresponding Author, Eng. Agr. Dr., Prof. Depto. de Fitotecnia-CCA, Universidade Federal de Santa Catarina, FlorianópolisSC, 88034-001, Brazil, E-mail: mpguerra@cca.ufsc.br

2. Eng ${ }^{\circ}$. Agr ${ }^{\circ}$. MSc. Laboratório de Fisiologia do Desenvolvimento e Genética Vegetal, CCA, UFSC

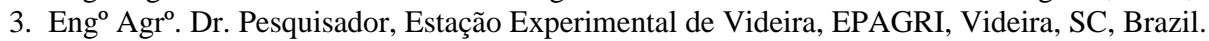


dos foram estudados no presente trabalho visando elucidar pontos de controle da embriogênese somática. Assim, embriões zigóticos excisados de frutos maduros de cinco acessos de Feijoa sellowiana Berg, foram avaliados quanto ao seu potencial embriogenético. Choques auxínicos de 2,4-D (20 $\mu \mathrm{M}) \mathrm{em}$ períodos de 1, 2, 4, 8 e 16 semanas foram utilizados para estabelecer o período mínimo de aquisição de competência embriogênica dos explantes e o posterior efeito deste fitorregulador sobre o desenvolvimento e qualidade dos embriões somáticos. Diferentes composições de cápsulas de alginato foram empregadas para avaliar a polimerização das cápsulas e a contaminação das sementes sintéticas. A maior percentagem de indução da embriogênese somática e o maior número de embriões ocorreram nos acessos 101 e 50-4. Choques de 2,4-D de duas semanas foram suficientes para proporcionar valores similares de indução e produção de embriões somáticos, àqueles obtidos com choques de 4 e 8 semanas. Estudos histológicos demonstraram a origem direta da embriogênese somática a partir da epiderme cotiledonar. A adição dos sais de MS e sacarose ao alginato de sódio resultou em altos valores de contaminação das sementes sintéticas, quando comparados às capsulas isentas destas substâncias. $\mathrm{O}$ emprego do $\mathrm{KNO}_{3}(100 \mathrm{mM})$ permitiu a despolimerização e a abertura de $81,2 \%$ das sementes sintéticas em comparação aos valores de $0 \%$ para o tratamento com água.

TERMOS ADICIONAIS PARA INDEXAÇÃO: Acca sellowiana, micropropagação, goiabeira serrana, encapsulamento.

\section{INTRODUCTION}

Somatic embryogenesis

(SE)

recapitulates morphologic and developmental events that occur in the zygotic embryogenesis. In vitro $\mathrm{SE}$ takes place in the absence of vascular connections with the mother-plant (Zimmerman, 1993). Following appropriate induction, somatic cells can generate a complete plant, since they contain a complete set of genetic information (Merkle et al., 1995). The competence of cells, tissues, and organs in response to specific environmental or chemical signals, may be the starting point to new developmental programs leading to in vitro SE induction (Yeung, 1995).

The induction and control of somatic embryogenesis are dependent of the explant source, the genotype of the mother plant, and the type and level of growth regulators supplemented to culture medium with 2,4-D as the auxin normally employed for the induction of embryogenic competence (Guerra et al., 1999).

Once obtained a somatic embryo can be stored as a synthetic seed. The synthetic seed technology based on the encapsulation of somatic embryos in a hydrogel capsule was proposed by Redenbaugh et al., (1986). The main advantages of this technology is are protection of the somatic embryos and ease in storage, conservation, transport and conversion to plantelts (Onishi et al., 1994, Guerra et al., 1999).

The 'goiabeira serrana' (Feijoa

sellowiana Berg, synonymous of Acca sellowiana (Berg.) Burr.) is a fruit species native of the South of Brazil and North of Uruguay, where it is not yet commercially cultivated. The naturally occurring populations in Santa Catarina State show great variability in the fruit size, color and other features (Nodari et al., 1997). In New Zealand, Australia, USA and some countries of Europe it has been cultivated in commercial orchards since the begining of the $20^{\text {th }}$ century (Ducroquet and Hickel, 1997).

Conventional techniques of vegetative propagation of $F$. sellowiana based on cuttings are difficult because of the low rates of success. Apparently, the phenol oxidation negatively affects the percentage of rooting (Duarte et al., 1992; Fachinello et al., 1992).

Micropropagation techniques have been used to overcome such problems. Various reports of the application of tissue culture techniques based on organogenesis in this species have been published elsewhere (Bhojwani et al., 1987; Canhoto \& Cruz, 1996a; Dal Vesco and Guerra, 
1999; Oltramari et al., 2000). These protocols have been based on the culture of nodal segments, apical and axillary bud, and microcuttings, generally showing low efficiency in terms of regenerative potential. In parallel, research efforts have been alternatively directed to the induction and control of somatic embryogenesis. Thus, protocols concerning this morphogenetic pathway were developed by Cruz et al., (1990), Canhoto and Cruz (1994, 1996b), and Guerra et al., (1997), Dal Vesco and Guerra (2001) aiming at the mass propagation of superior genotypes.

Therefore, the purposes of the present work were to study (a) the role of shocks of 2,4-D in the induction of $F$. sellowiana embryogenic competence; (b) the influence of the mother plant genotype in the induction and control of in vitro somatic embryogenesis of $F$. sellowiana, and; (c) the use of the synthetic seed technology for the encapsulation and handling of somatic embryos of this species.

\section{MATERIAL AND METHODS}

\section{Plant material}

Mature zygotic embryos were collected from fruits of selected mother plants maintained at the germplasm collection of the Experimental Station of São Joaquim (EPAGRI). These fruits were transported to the Laboratory of Developmental Physiology and Plant Genetics, Depto. de Fitotecnia, Universidade Federal de Santa Catarina, Brazil. The seeds, collected 135 days after anthesis were extracted and disinfected with ethanol $(70 \%)$ for $1 \mathrm{~min}$; commercial bleach $(2.0 \% \mathrm{NaClO})$ for $20 \mathrm{~min}$ and then rinsed three times with sterile water. The zygotic embryos were excised in aseptic chamber and innoculated in test tubes $(25 \times 150 \mathrm{~mm})$ containing $15 \mathrm{~mL}$ of basal medium LPm (von Arnold and Eriksson, 1981) supplemented with Morel's vitamins (Morel and Wetmore, 1951), sucrose (3\%), and Phytage ${ }^{\circledR}$ $(0.2 \%)$. The $\mathrm{pH}$ was adjusted to 5.8 prior to autoclaving. The cultures were maintained in culture room in the dark at $25{ }^{\circ} \mathrm{C}$ during the induction phase. For somatic embryo conversion the cultures were kept at the photosynthetic photon flux of $40 \mu \mathrm{mol} \mathrm{m} \mathrm{m}^{-2} \mathrm{~s}^{-1}$ provided by cool white lamps and $16 \mathrm{~h} \mathrm{~d}^{-1}$ photoperiod

\section{Effect of Genotypes}

Zygotic embryos of different genotypes of $F$. sellowiana were employed to evaluate somatic embryogenesis induction. The basal LPm medium was supplemented with 2,4-D $(20 \mu \mathrm{M})$ and L-Gln $(4 \mathrm{mM})$. The experiment was arranged in a completely randomized design (CRD) with five $F$. sellowiana genotypes: 50-4, 53B-7, 101, 529 , and $152-12 \times 458$ from the germplasm collection. Each experimental unit was consisted of ten explants, replicated four times. The percentages of explants having embryos and the number of viable somatic embryos per explant was recorded after 5, 10 and 15 weeks in culture, and submitted to Analysis of Variance (ANOVA).

\section{Shock of 2,4-D}

Zygotic embryos of the genotype 101 were excised and then inoculated in the basal LPm medium supplemented with 2,4-D $(20 \mu \mathrm{M})$ and Gln $(4 \mathrm{mM})$. The experiment was arranged in a CRD with 1, 2, 4, 8 and 16 weeks intervals of incubation time in culture medium supplemented with 2,4-D. Each experimental unit was consisted of 10 explants replicated four times. After the shock period the cultures were transferred to the LPm basal medium. The percentage of induction and the number of somatic embryos per explant were recorded after 5, 10, 15 and 20 weeks in culture, and the percentage of explants with somatic embryos were submitted to regression analysis.

\section{Histology}

Samples were selected and fixed in solution $2.5 \%$ glutaraldheyde in phosphate buffer (0.1 M, pH 6.8) and dehydrated in an ethanol ascending series, xilol and embedded in paraffin wax (Sass, 1951). Serial sections $(8-12 \mu \mathrm{m})$ were 
obtained using a rotary microtome Slee Technik ${ }^{\circledR}$ and stained with safranin and fast-green.

\section{Synthetic seeds}

Pre-germinated torpedo and cotyledonary somatic embryos after two weeks in basal culture medium containing Kin $(0.5 \mu \mathrm{M})$ and $\mathrm{GA}_{3}(0.5$ $\mu \mathrm{M})$, were encapsulated in sodium alginate $1 \%$ (Carlo Erba $\left.{ }^{\circledR}\right)$ and immediately complexed in $\mathrm{CaCl}_{2}(50 \mathrm{mM})$ during $20 \mathrm{~min}$. The capsules were then stored at $4^{\circ} \mathrm{C}$ for different periods of times. A treatment combination of three factors $(4 \times 4 \times 2)$ was employed. In the first factor, four types of artificial endosperm added to sodium alginate were tested: (i) $\mathrm{GA}_{3}(0.05 \mu \mathrm{M})+\mathrm{Kin}(0.05 \mu \mathrm{M})$; (ii) $1 / 2 \mathrm{MS}+$ $\mathrm{GA}_{3}(0.05 \mu \mathrm{M})+\mathrm{Kin}(0.05 \mu \mathrm{M})$; (iii) $1 / 2 \mathrm{MS}+$ sucrose $(2 \%)+\mathrm{GA}_{3}(0.05 \mu \mathrm{M})+\operatorname{Kin}(0.05 \mu \mathrm{M})$; and (iv) $1 / 2 \mathrm{MS}+$ sucrose $(2 \%)+\mathrm{GA}_{3}(0.05 \mu \mathrm{M})+$ Kin $(0.05 \mu \mathrm{M})+\mathrm{CH}(500 \mathrm{mg} / \mathrm{l})$. As the second factor, different periods of storage at $4^{\circ} \mathrm{C}$ (one, two, three, and four weeks), were tested. Two treatments of capsule opening, with immersion in $100 \mathrm{mM}$ of $\mathrm{KNO}_{3}$ or distilled water during $20 \mathrm{~min}$ were also employed as levels of the third factor. Each experimental unit was constituted by five capsules, replicated three times and arranged as a CRD. Five weeks after the transference to petri dishes containing distilled water the conversion rate and the frequencies of contamination were recorded.

\section{Statistical analysis}

Data on percentage, number and conversion of somatic embryos were submitted to the test of F-maximum. When necessary, the data were transformed to $\log (x+2)$ or $(x+0.5)^{0.5}$. The data were then submitted to Analysis of Variance, to the Student-Newman-Kuels (SNK) test, and to the Regression Analysis, according to Sokal and Rohlf (1995).

\section{RESULTS AND DISCUSSION}

\section{Effect of Genotypes}

Out of five cultured genotypes three of them revealed significant $(\mathrm{P}<0.01)$ rate of somatic embryogenesis and yield of SE $(\mathrm{P}<0.05)$ after 10 weeks in culture (Figure 1a, b). Visual evaluations in stereomicroscope showed the presence of globular somatic embryos after four weeks in culture. This embryogenic induction occurred in at a low frequency and asynchronously. After five weeks in culture, heart and torpedo shaped somatic embryos were observed. Finally, after ten weeks in culture a high frequency of torpedo and cotyledonary somatic embryos was observed (Figure 2a). An increase in the rates of somatic embryogenesis induction was observed after ten weeks in culture as compared to the level recorded after five weeks in culture (Figure 1a, b). After 15 weeks in culture, a lower number of somatic embryos, some of them abnormal and whitishopaque, in comparison with those formed in shorter period treatments.

While the highest frequency and number of somatic embryos were observed in the genotypes 50-4 and 101, the genotype 53B-7 revealed the lowest induction rates and production of somatic embryos (Figure 1 and Figure $2 b$ ).

The induction and control of somatic embryogenesis in $F$. sellowiana has been associated with an interaction between the genotype of the mother plant and the constitution of the culture medium (Canhoto and Cruz, 1996a and Guerra et al., 1997). Genotype specificity for embryogenic induction was also reported in other embryogenic systems such as in conifers (Attree and Fowke, 1993), Vitis spp (Gray, 1995), Juglans spp (Preece et al., 1995), Theobroma cacao (Alemanno et al., 1996), and Gossypium hirsutum (González-Benito et al., 1997).

\section{2,4-D Shock}

The transfer of explants after two weeks in the culture medium containing 2,4-D to the culture medium free of growth regulators resulted in early production of somatic embryos in a large percentage of the explants (Figure 3a, b). However, when the cultures were submitted to a one-week shock of 2,4-D, then subcultured in a culture medium free of growth regulators, a low percentage of induction and a low number of 

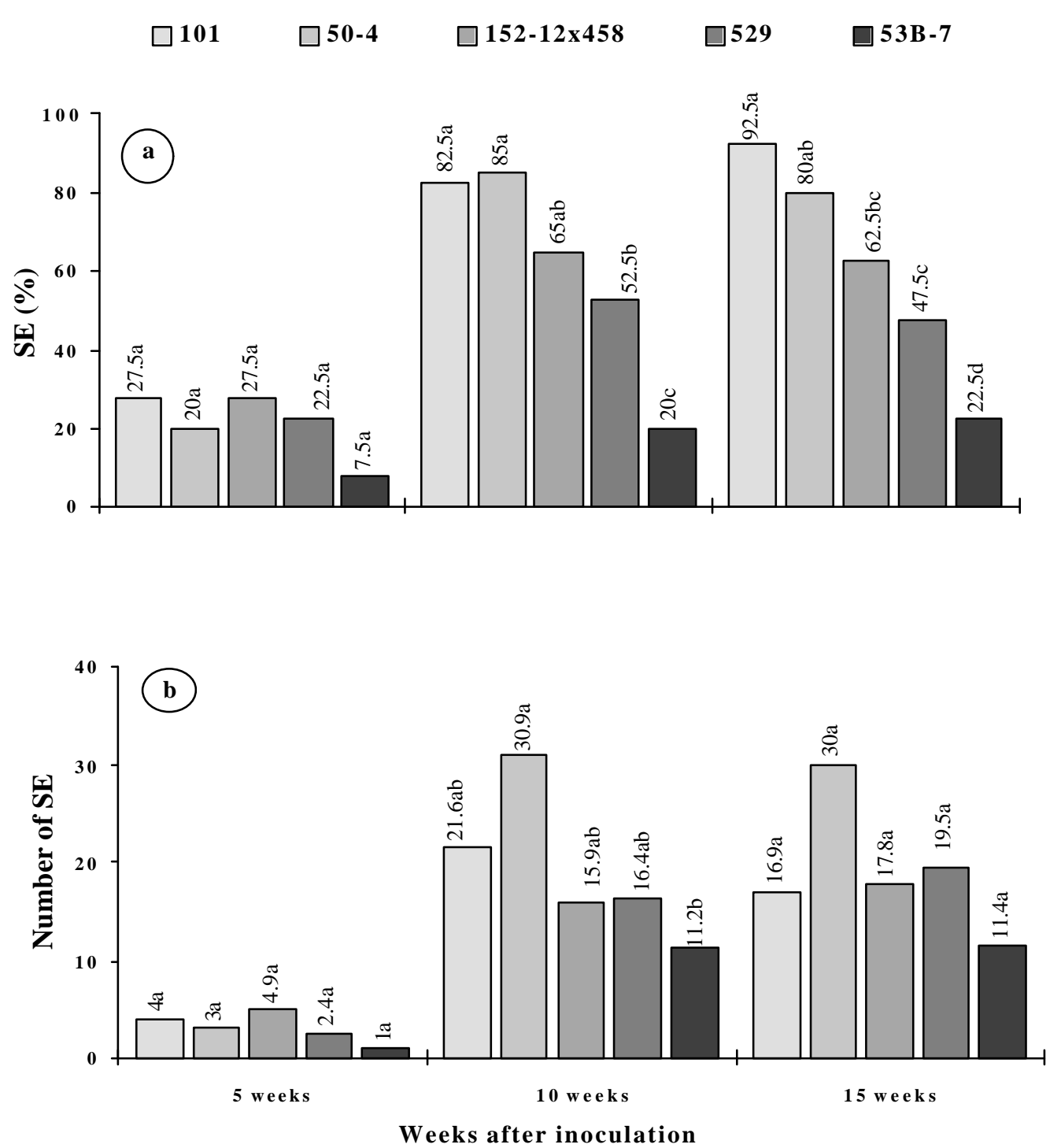

FIGURE 1 - Induction of somatic embryos (SE): a) percentage of $\mathrm{SE}^{\mathrm{a}} \mathrm{e}$ b) number of $\mathrm{SE}^{\mathrm{b}}$ per embryogenic explant, in five genotypes of F. sellowiana in LPm culture medium supplemented with 2,4$\mathrm{D}(20 \mu \mathrm{M})$, after different periods (weeks) of culture.

Means of four replicates. Values followed by same letters are not significantly different at the $5 \%$ level by SNK test.

${ }^{\mathrm{a}} \mathrm{CV}(\%)$ for $5 \mathrm{wk}=76.8 ; 10 \mathrm{wk}=20.5$ and $15 \mathrm{wk}=25.7$

${ }^{\mathrm{b}}(\mathrm{CV} \%)$ in $5 \mathrm{wk}=91.3 ; 10 \mathrm{wk}=23.0^{\mathrm{y}}$ and $15 \mathrm{wk}=51.2$.

${ }^{\mathrm{y}}$ data transformed for analysis using $(\mathrm{x}+0.5)^{0.5}$ 

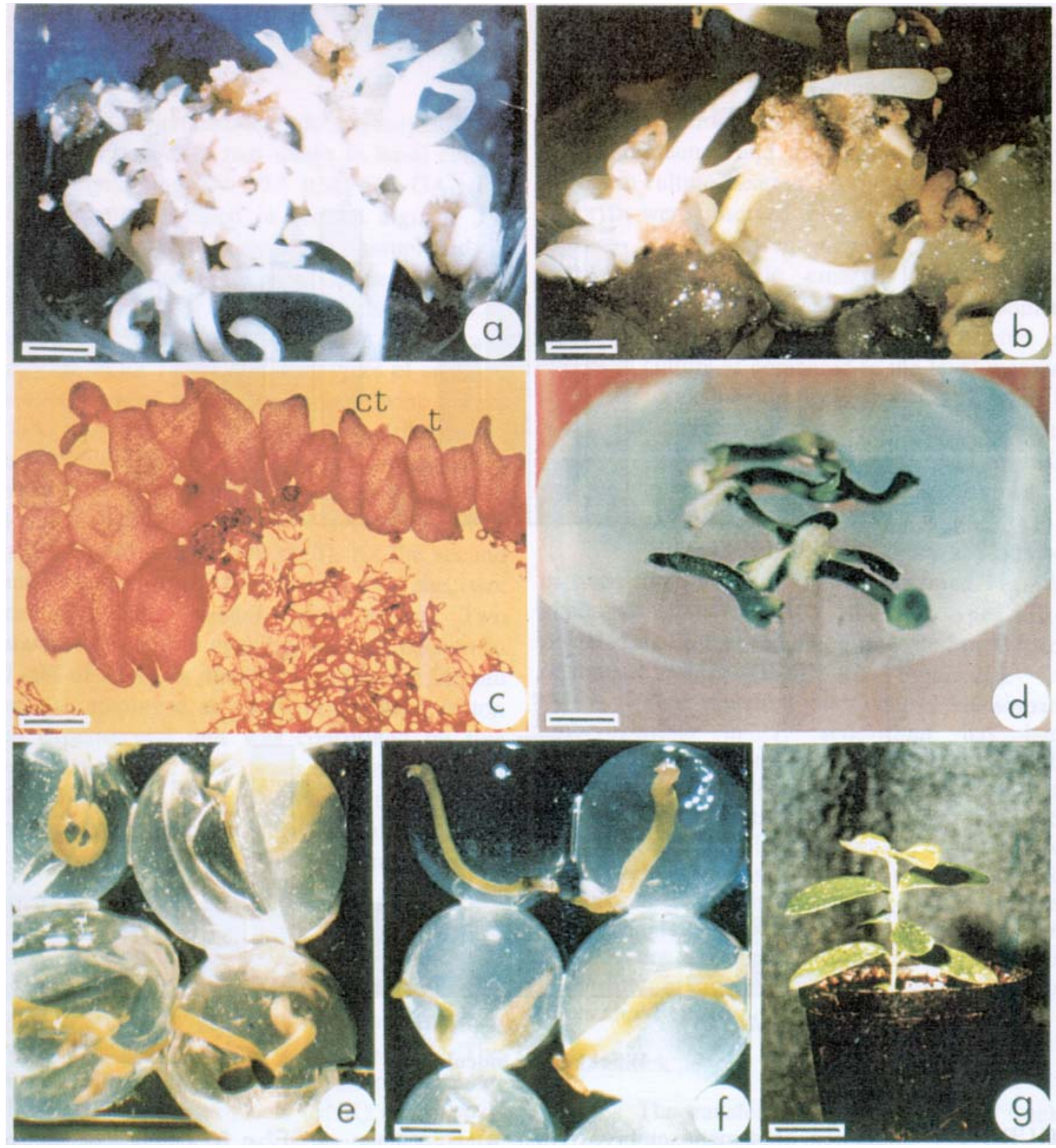

FIGURE 2 - a) High frequency and asynochronous somatic embryos (SE) of F sellowiana (bar: 2.6 $\mathrm{mm}$ ), b) low frequency SE (bar: $2.6 \mathrm{~mm}$ ); c) Transection of embryogenic culture showing different stages of SE, after 12 weeks in culture (t-torpedo stage; ct-cotyledonary stage; bar: $0.1 \mathrm{~mm}$ ) d) Pregerminated SE, after 2 weeks on basal culture medium (bar: $2.6 \mathrm{~mm}$ ); e) Synthetic seeds treated with $\mathrm{KNO}_{3}(100 \mathrm{mM})$ during $20 \mathrm{~min}$ (bar: $1.8 \mathrm{~mm}$ ); f) Synthetic seeds treated with water (bar: $1.8 \mathrm{~mm}$ ); g) Plantlets growing in soil after 10 weeks in greenhouse (bar: $3.2 \mathrm{~cm}$ ). 

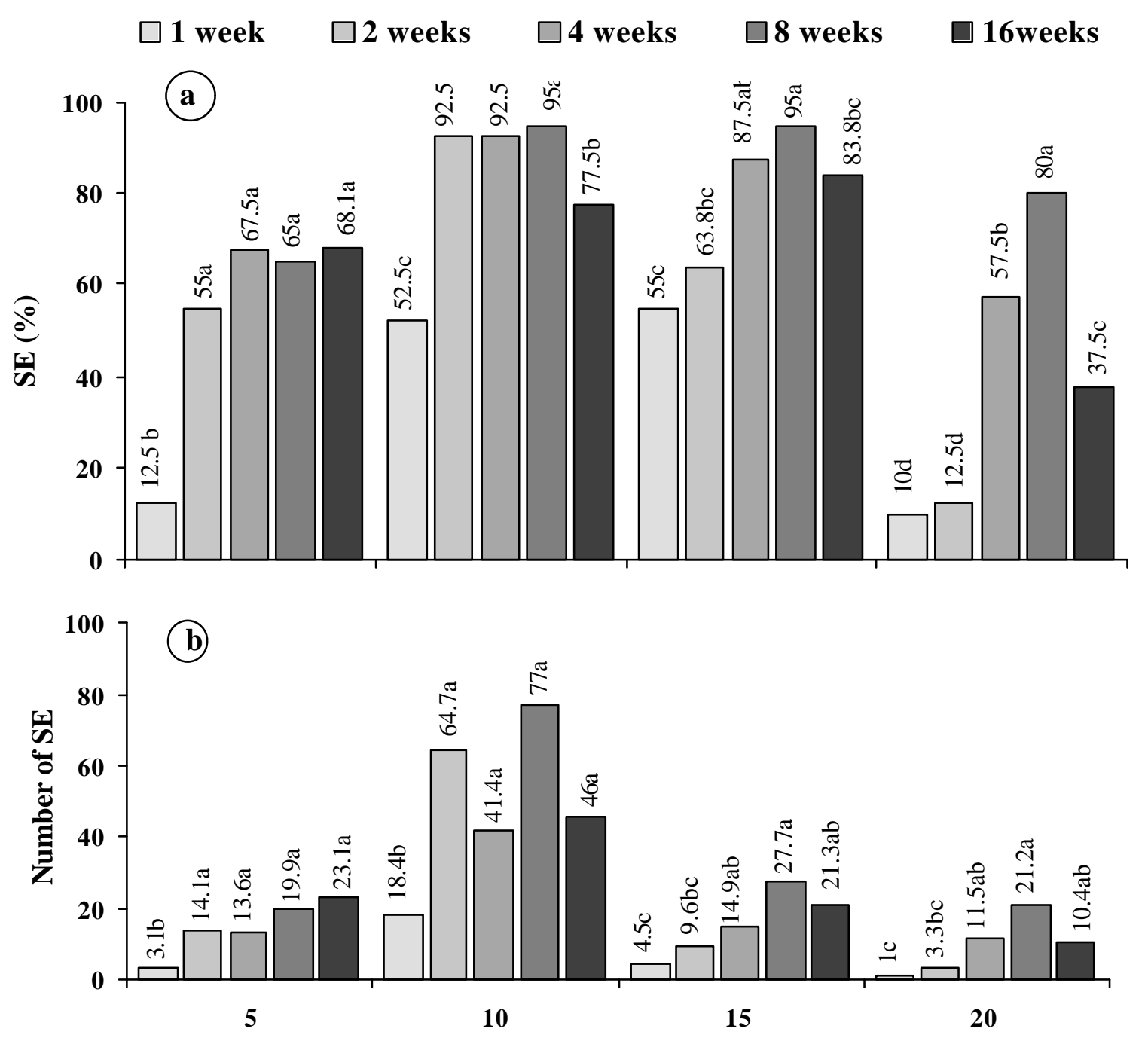

Weeks after inoculation

FIGURE 3 - Effect of shock of 1, 2, 4, 8 and 16 weeks of 2,4-D (20 $\mu \mathrm{M})$, a) percentage of somatic embryos (SE) ${ }^{\mathrm{a}}$, and b) number of SE per explant ${ }^{\mathbf{b}, \mathbf{y}}$ of genotype 101 of $F$. sellowiana, after different periods (week) of culture.

Means of four replicates. Values followed by the same letters are not significantly different at the 5\% level by SNK test.

${ }^{\mathrm{a}} \mathrm{CV}(\%)$ in $5 \mathrm{wk}=28.9 ; 10 \mathrm{wk}=9.7 ; 15 \mathrm{wk}=19.0$ and $20 \mathrm{wk}=33.5$

${ }^{\mathrm{b}} \mathrm{CV}(\%)$ in $5 \mathrm{wk}=24.4 ; 10 \mathrm{wk}=18.2 ; 15 \mathrm{wk}=22.0$ and $20 \mathrm{wk}=35.5$.

${ }^{\mathrm{y}}$ data transformed for analysis using $(\mathrm{x}+0.5)^{0.5}$ 
somatic embryos were observed after ten weeks in culture. In these two treatments, the induction of somatic embryogenesis culture. In these two treatments, the induction of somatic embryogenesis occurred directly from the cotyledonary surface of the zygotic embryos used as explants and evolved rapidly to the cotyledorary stage. This was confirmed by anatomic and histological studies showing that the globular somatic embryos originated directly from the epidermic cell layers of cotyledon, after five weeks in culture (Figure 2c).

Previously, Cruz et al., (1990) showed that the culture of explants during five days in medium culture supplemented with 2,4-D, was sufficient to promote the somatic embryogenesis in F. sellowiana. Thus, the present work supports the role of 2,4-D in the promotion of Feijoa somatic embryogenesis.

The group of cells present in the cotyledonary surface of zygotic embryos of $F$. sellowiana was termed meristematic cells (Canhoto and Cruz, 1996b), or embryogenic cells, since they do not need long exposition time to auxins to induce somatic embryogenesis (de Jong et al., 1993; Guerra et al., 1999). In adequate culture conditions these cells are competent to launch an embryogenetic developmental program, resulting in the production of somatic embryos, mimicking the developmental pattern of zygotic embryogenesis (Zimmerman, 1993; Toonen et al., 1996). These results suggest that, under certain conditions, these cells may be competent to originate synchronously high frequency of somatic embryos (Osuga and Komamine, 1994).

A shock of 16 weeks with 2,4-D negatively affected the induction rate and the development of somatic embryos (Figure 3a, b), suggesting that the maintenance of primary cultures of $F$. sellowiana in the presence of this growth regulator may originate some abnormalities in somatic embryo development. However, the permanence during eight weeks of the somatic embryos in the culture medium containing 2,4-D, resulted in a decrease in the frequency of induction of somatic embryos after 15 weeks in culture after shock (Figure 4). According with these data the quadratic adjustment showed high and significant $\mathrm{r}^{2}$ and P-values. The adjusted model allowed us to estimate that the highest induction rate $(98.7 \%$ in 13.5 weeks in culture after shock) was obtained with eight weeks 2,4-D shock. Four and two weeks 2,4-D shock resulted in $93.7 \%$ and $86.4 \%$ of embryogenic induction after 11.9 and 10.7 weeks in culture after shock, respectively. Cruz et al., (1990) also observed in F. sellowiana that long periods in the presence of 2,4-D did not improve the embryogenic response. In Carica pubescens the best induction and formation of somatic embryos occurred with shocks of six days in culture medium supplemented with 2,4-D plus BAP (Jordan and Velozo, 1996).

The results of the present work showed that low exposition time in 2,4-D was associated with a very rapid differentiation and development of somatic embryos, which showed increased germination rates. These results suggest that the correct manipulation of this growth regulator in the induction phase of $F$. sellowiana somatic embryogenesis is a key factor to the establishment of its regenerative protocol and the commercial viability of these micropropagation system.

\section{Synthetic seeds}

Pre-germinated torpedo shaped somatic embryos (Figure 2d) were utilized for encapsulation. Polymerization of sodium alginate $(1 \%)$ in $\mathrm{CaCl}_{2}(50 \mathrm{mM})$ resulted in the formation of hydrogel capsules with somatic embryos inside. The treatment with $\mathrm{KNO}_{3}(100 \mathrm{mM})$ during $20 \mathrm{~min}$ resulted in high rate of capsules opening (Table 1) of the synthetic seeds (Figure 2e) as compared to the treatment with distilled water (Figure 2f). Increasing levels of nutrients and sucrose for the reconstitution of a synthetic endosperm resulted in high rates of capsule contamination during the incubation period.

In the technology of synthetic seeds, the use $\mathrm{KNO}_{3}$ has been proposed in order to soften the 
hidrogel capsule. Since the sodium alginate is complexed by $\mathrm{Ca}^{+2}$ ions, the resulting synthetic seed is stored in the form of a hard capsule. The mechanical resistance of the capsule in association with the low temperature of storage prevents the germination of the encapsulated somatic embryo. The results of the present work (Table 1) showed that the germination of the encapsulated somatic embryo is facilitated by a pre-treatment of the synthetic seed with a solution of $\mathrm{KNO}_{3}(100 \mathrm{mM})$, resulting in $81.2 \%$ of opened capsules as compared with $0 \%$ in the treatment with water. The best $\mathrm{KNO}_{3}$ concentration resulted from previous experiments (data not shown). According to Onishi et al., (1994) the $\mathrm{K}^{+}$ions from $\mathrm{KNO}_{3}$ replaces the $\mathrm{Ca}^{+2}$ of the calcium alginate capsule thus allowing the softening and opening of the synthetic seed and the subsequent germination of the somatic embryos. Dal Vesco \& Guerra (2001) showed that the conversion of $F$. sellowiana somatic embryos to plantlets was enhanced by culturing them in halfstrenght MS culture medium supplemented with $\operatorname{BAP}(0.5 \mu \mathrm{M})$.

The conversion of somatic embryos was possible in autoclaved soil and the derived plantlets were successfully acclimatizated (Figure 2g ).

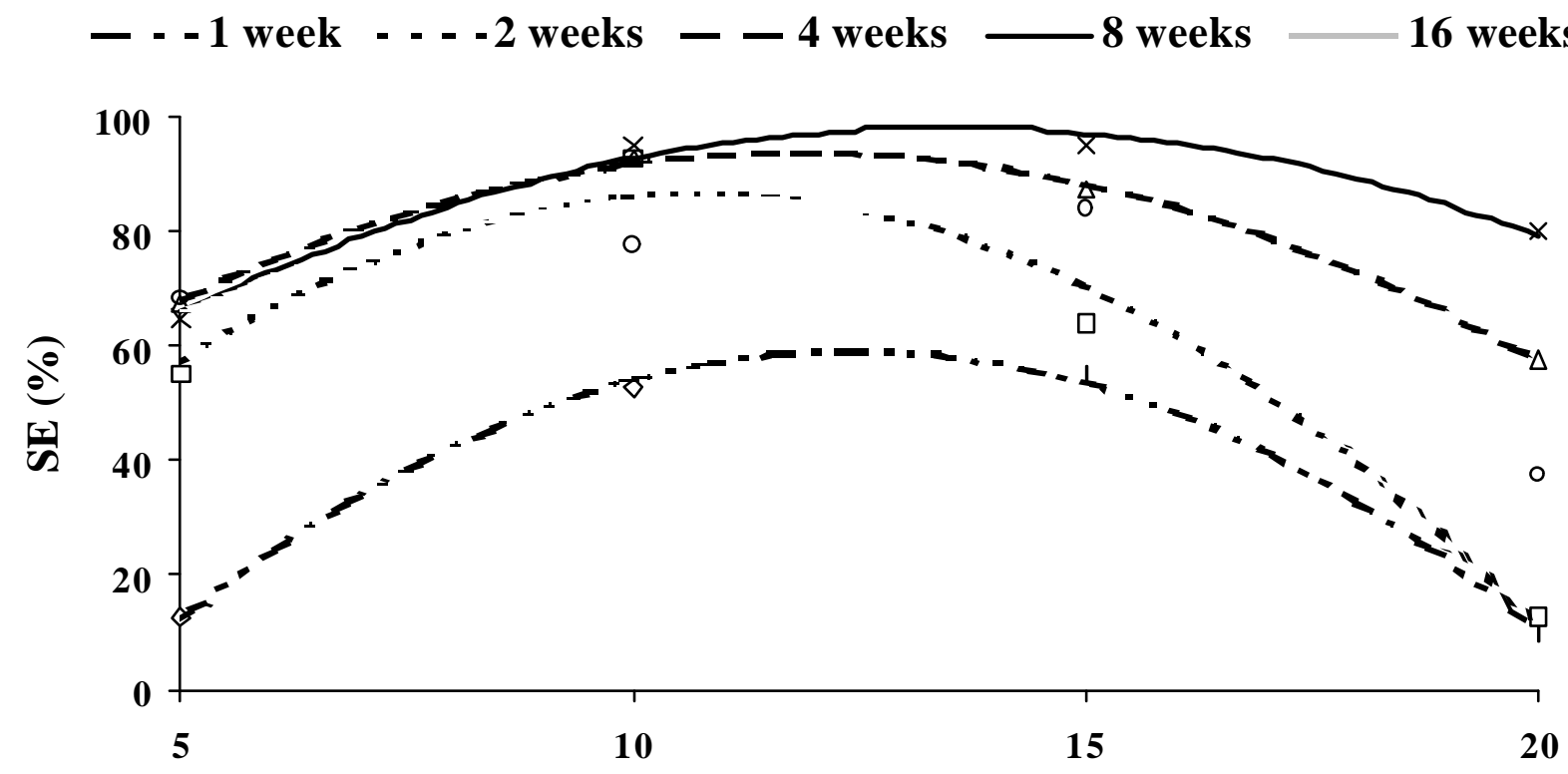

\section{Weeks after inoculation}

$$
\begin{array}{llll}
Y_{(1 w k)}=-72.5+21.15 x-0.85 x^{2} & r^{2}=0.997 & Y_{(8 w k)}=16.25+12.15 x-0.45 x^{2} & r^{2}=0.982 \\
Y_{(2 w k)}=-16+19.08 x-0.89 x^{2} & r^{2}=0.971 & Y_{(16 w k)}=18.47+12.22 x-0.56 x^{2} & r^{2}=0.903 \\
Y_{(4 w k)}=16.25+13.05 x-0.55 x^{2} & r^{2}=0.998 & &
\end{array}
$$

FIGURE 4 - Effects of 2,4-D (20 $\mu \mathrm{M})$ shock (1, 2, 4, 8 and 16 weeks) on percentage of somatic embryos (SE) of the genotype 101 of $F$. sellowiana as a function of time (weeks) in LPm culture medium. Each value represents the means of four replicates. 
TABLE 1 - Effect of different artificial endosperm and time of storage at $4^{\circ} \mathrm{C}$ in the contamination of synthetic seeds and effect of $\mathrm{KNO}_{3}$ on the opening of capsules, five weeks after the transference to incubation.

\section{Artificial Endosperm}

\begin{tabular}{lc}
\hline Sodium alginate plus: & Contamination (\%) \\
$\mathrm{GA}_{3}(0.05 \mu \mathrm{M})+\operatorname{Kin}(0.05 \mu \mathrm{M})$ & $36.6 \mathrm{a}$ \\
$1 / 2 \mathrm{MS}+\mathrm{GA}_{3}(0.05 \mu \mathrm{M})+\mathrm{Kin}(0.05 \mu \mathrm{M})$ & $72.4 \mathrm{~b}$ \\
$1 / 2 \mathrm{MS}+\operatorname{sucrose}(2 \%)+\mathrm{GA}_{3}(0.05 \mu \mathrm{M})+\operatorname{Kin}(0.05 \mu \mathrm{M})$ & $77.6 \mathrm{~b}$ \\
$1 / 2 \mathrm{MS}+\operatorname{sucrose}(2 \%)+\mathrm{GA}_{3}(0.05 \mu \mathrm{M})+\operatorname{Kin}(0.05 \mu \mathrm{M})+$ Casein $(500 \mathrm{mg} / \mathrm{l})$ & $80.8 \mathrm{~b}$
\end{tabular}

Storage in $4{ }^{\circ} \mathrm{C}$

Number of weeks

Contamination $(\%)$

1

54.2 a

2

$60.8 \mathrm{a}$

4

$75.0 \mathrm{~b}$

3

$77.6 \mathrm{~b}$

\section{Opening Capsule}

Treatments

Opened Capsule $(\%)$

$\mathrm{KNO}_{3}$

$81.2 \mathrm{a}$

Control $\left(\mathrm{H}_{2} \mathrm{O}\right)$

$0.0 \mathrm{~b}$

Means of three replicates. Values followed by same letters are not significantly different at the $5 \%$ level by SNK test.

In conclusion, the results obtained in the present work showed that somatic embryogenesis in Feijoa sellowiana is dependent, among other factors on the genotype of the mother plant. A single shock of two weeks in 2,4-D conferred embryogenic competence and allowed the development of morphological normal somatic embryos. Anatomic and histological studies showed that the somatic embryos originated directly from the epidermic cell layers of cotyledon of zygotic embryos used as explant. Those somatic embryos once encapsulated in synthetic seeds containing MS salts and sucrose resulted in higher rates of contamination than capsules free of these 
substances. To complete the cycle, the treatment of synthetic seeds with $\mathrm{KNO}_{3}(100 \mathrm{mM})$ allowed the opening of $81.2 \%$ of the capsules as compared to $0 \%$ of opening in the treatment with water.

Besides elucidating some of the control points of the somatic embryogenesis in this species towards the establishment of a mass clonal micropropagation system, the results obtained in the present work provided additional support for this species to be used as a reference system to the somatic embryogenesis in woody dicots.

\section{REFERENCES}

ALEMANNO, L.; BERTHOULY, M. \& MICHAUX-FERRIÈRE, N.A. Histology of somatic embryogenesis from floral tissues of cocoa. Plant Cell, Tissue and Organ Culture, 46:187-194, 1996.

ATTREE, S. \& FOWKE, L. Embryogeny of Gymnosperms: Advances in Synthetic Seed technology of conifers. Plant Cell, Tissue and Organ Culture, 35:1-35, 1993.

BHOJWANI, S.S., MULLINS, K. \& COHEN D. Micropropagation of Feijoa sellowiana Berg. Acta Horticulturae , 212:69-76, 1987.

CANHOTO, J.M. \& CRUZ, G.S. Feijoa sellowiana Berg (Pineapple Guava). In: BAJAJ, Y.P.S. (ed.). Biotechnology in Agriculture and Forestry. Trees IV, Berlin, Springer-Verlag, v.35, p.156-172, 1996a.

CANHOTO, J.M. \& CRUZ, G.S. Histodifferentiation of somatic embryos in cotyledons of pineapple guava (Feijoa sellowiana Berg). Protoplasma, 191:34-45, 1996b.

CANHOTO, J.M. \& CRUZ, G.S. Improvement of somatic embryogenesis in Feijoa sellowiana Berg (Myrtaceae) by manipulation of culture media composition. In Vitro Cellular and Developmental Biology-Plant, 30:21-25, 1994.
CRUZ, G. S.; CANHOTO, J.M. \& ABREU, M.A.V. Somatic embryogenesis and plant regeneration from zygotic embryos of Feijoa sellowiana Berg. Plant Science, 66:263-270, 1990.

DAL VESCO, L.L. \& GUERRA, M.P. Micropropagação da goiabeira serrana (Feijoa sellowiana Berg.) I: Fatores determinantes da organogênese. Revista Brasileira de Fruticultura, 21:60-64, 1999.

DAL VESCO, L.L. \& GUERRA, M.P. The effectiveness of nitrogen sources in Feijoa somatic embryogenesis. Plant Cell, Tissue and Organ Culture, 64:19-25, 2001.

DE JONG, A.J.; SCHMIDT, E.D.L. \& VRIES, S.C. Early events in higher-plant embryogenesis. Plant Molecular Biology, 22:367-377, 1993.

DUARTE, O.R.; FACHINELLO, J.C. \& SANTOS FILHO. B.G. dos. Multiplicação da goiabeira serrana através de estacas semilenhosas. Pesquisa Agropecuária Brasileira, 27:513516, 1992.

DUCROQUET, J.P.H.J. \& HICKEL, E.R. Birds as pollinators of feijoa (Acca sellowiana Berg). Acta Horticulturae, 452:37-40, 1997.

FACHINELLO, J.C.; MIELKE, M.S. \& NACHTIGAL, J. de C. Propagação vegetativa de goiabeira serrana. Revista Brasileira de Fruticultura, 14:233-236, 1992.

GONZÁLEZ-BENITO, M.E.; FROTA-CHAGAS CARVALHO, J.M. \& PÉREZ, C. Somatic embryogenesis of an early cotton cultivar. Pesquisa Agropecuária Brasileira, 32:485488, 1997.

GRAY, D.J. Somatic embryogenesis in grape. In: JAIN, S.M.; GUPTA, P.K.; NEWTON, R.J. (eds.), Somatic embryogenesis in woody plants, Angiosperms. Dordrecht, Kluwer Academic Pub., 1995. v.2, p.191-217. 
GUERRA, M.P.; PESCADOR. R. DAL VESCO, L.L.; NODARI, R.O. \& DUCROQUET, J.P.H.J. In vitro morphogenesis in Feijoa sellowiana: Somatic embryogenesis and plant regeneration. Acta Horticulturae, 452:27-36, 1997.

GUERRA, M.P., TORRES, A.C. \& TEIXEIRA, J.B. Embriogênese somática e semente sintética. In: TORRES, A.C. CALDAS, L.S \& BUSO, J.A. (eds.). Cultura de Tecidos e Transformação Genética de Plantas. Brasília, EmbrapaSPI/CNPH, 1999. v.2, p.533- 568.

JORDAN, M. \& VELOZO, J. Improvement of somatic embryogenesis in highland-papaya cell suspensions. Plant Cell, Tissue and Organ Culture, 44:189-194, 1996.

MERKLE, S.A.; PARROTT, W.A. \& FLINN, B.S. Morphogenic aspects of somatic embryogenesis. In: THORPE, T.A. (ed.), In vitro embryogenesis in plants. Dordrecht, Kluwer Academic Pub. 1995. p.155-203.

MOREL, G.M. \& WETMORE, R.H. American Journal of Botany, 38:138-140, 1951.

MURASHIGE, T.; SKOOG, F. A revised medium for rapid growth and bioassays with tobacco tissue cultures. Physiology Plantarum, 15:473-497, 1962.

NODARI, R.O.; GUERRA, M.P.; MELER, K. \& DUCROQUET, J.P. Genetic variability of Feijoa sellowiana germplasm. Acta Horticulturae, 452: 41-46, 1997.

OLTRAMARI, A.C.; DAL VESCO, L.L.; PEDROTI, E.L.; DUCROQUET, J.P.H.J; NODARI, R.O. \& GUERRA, M.P. Desenvolvimento do protocolo de micropropagação da goiabeira serrana (Acca sellowiana (Berg) Burret). Ciência Rural. 30: 61-68, 2000.

ONISHI, N.; SAKAMOTO, Y. \& HIROSAWA, T. Synthetic seed as an application of mass production of somatic embryos. Plant Cell, Tissue and Organ Culture, 39:137-145, 1994.
OSUGA, K. \& KOMAMINE, A. Synchronization of somatic embryogenesis from carrot cells at high frequency as a basis for the mass production of embryos. Plant Cell, Tissue and Organ Culture, 39:125-125, 1994.

PREECE J.E.; MCGRANAHAN, G.H.; LONG, L.M. \& LESLIE, C.A. Somatic embryogenesis in walnut (Juglans regia). In: JAIN; S.M. GUPTA, P.K. \& NEWTON, R.J. (eds.), Somatic embryogenesis in woody plants, Angiosperms. Dordrecht, Kluwer Academic Pub. 1995. v.2 p. 99-116.

REDENBAUGH, K.; PAASH, B.; NICHOL, J.; KOSSLER, M.E.; VISS, P. \& WALKER, K.A. Synyhetic seeds: encapsulation of asexual plant embryos. Bio/Technology, 4:797-801, 1986.

SASS, I.E. Botanical microtechnique . New York: The Iowa State Coll. Press. 1951.

SOKAL, R.R. \& ROHLF, F.J. Biometry. $3^{\mathrm{a}}$. ed. New York: W.H. Freeman, 1995. 881 p.

TOONEN, M.A.J.; SCHMIDT, E.D.L. \& VRIES, S.C. de. Cell tracking as a tool to study initial processes in somatic embryo development. Plant Tissue Culture and Biotechnology, 2:3 10, 1996.

VON ARNOLD, S. \& ERIKSSON, T. In vitro studies of adventitious shoot formation in Pinus contorta. Canadian Journal of Botany, 59:870-874, 1981.

YEUNG, E.C. Structural and developmental patterns in somatic embryogenesis. In: THORPE, T.A. (Ed.) In vitro embryogenesis in plants. Dordrecht, Kluwer Academic Pub, 1995. p. 205-247.

ZIMMERMAN, J.L. Somatic embryogenesis: a model for early development in higher plants. The Plant Cell, 5:1411-1423, 1993. 